omists, especially in developing countries, who are inclined favorably toward central planning will probably not read these books, but if any of them happen to, they will not be persuaded by their arguments. Unfortunately, a more precise and better developed methodology would be required to reconcile these divergent views.

Sirc seems to believe that it is sufficient to quote repentant East European planners, many of whom are as ready to heap abuse on the old model as they were once eager to uphold it, to clinch the case for market-type decentralization. But this will not do. Beyond a certain point, neither the indiscriminate damning of the old ways nor the exuberant expectations placed in the new can make up for the lack of a balanced appraisal of the advantages and disadvantages of centrally and decentrally coordinated systems at different stages of development, in different political and social milieus, for the different goals pursued by the ultimate authorities in various societies. It may matter very much, for instance, whether resources are mobilized for growth by Soviet-style methods at an early or at a mature stage of industrialization. (To argue, as Sirc does on page 29 , that Czech economists now recognize that fundamental errors were made in the allocation of resources fifteen or twenty years ago, at an earlier stage of development of their country, does not really meet the point.) This proposition should be tested statistically, not rejected a priori on the basis of casual observation. Is it likely, furthermore, that the optimal system for economies preparing for war, as the East European states were in the early 1950s, should have been as decentralized as the one that the Hungarians wish to implant today? Neither Sirc nor Gamarnikow makes a proper allowance for these extraneous factors, which cannot but influence the relation between an economy's system and the outcomes actually observed over a period of time and which must thus affect the choice of the best system under a given set of conditions. The unrigorous approach of both authors to these complex problems could perhaps be justified if the decentralized market system "dominated" all possible alternatives, that is, if it could be expected to yield the most desired outcomes for any goals and for all likely circumstances. To establish that proposition, or any one close to it in its degree of generality, Sirc and Gamarnikow would have had to be much more methodical in collecting and treating their facts. Irrespective of the outcome, they would then have written more substantial and lasting studies.

John Michael Montias Yale University

\title{
THE HOP INDUSTRY OF EASTERN EUROPE AND THE SOVIET UNION. By David A. Strausz. Pullman: Washington State University Press, 1969. 242 pp. $\$ 8.00$.
}

Hops are at best an unusual commodity. Though consumed indirectly by millions of beer drinkers throughout the world, their characteristics are virtually unknown to all except hop growers and dealers, brewmasters, and an occasional botanist.

It is therefore both unusual and refreshing to find in Professor Strausz's book a lucid, highly readable description of the hop crop, including its climatic and ecological requirements and growing techniques. But far more important, Strausz provides a penetrating and well-documented appraisal of the successes, failures, and prospects of this highly specialized facet of agriculture in Eastern Europe. Strausz brings to his subject not only professional competence as a geographer but also a most unusual attribute-he is an experienced and successful hop grower. Moreover, he gives firsthand observations on all the countries covered, including extensive 
interviews with nearly all the local authorities on hops. Strausz's ability to read and converse in Russian helped him to gather accurate information.

A most interesting and useful aspect of the book is its delineation of the wide variation in agricultural success achieved under communism, at least in the hop industry. Czechoslovakia and Yugoslavia, the author makes clear, have had outstanding success with widely different organizational approaches. Indeed, within Yugoslavia the differences between the Savinja region and the Bački Petrovac area are marked, and the fact that both areas are of major importance in the world hop market receives deserved emphasis. Similarly, Strausz makes it clear that Poland and the Soviet Union have failed to meet the challenges of modern technology and are unlikely to win significant shares of the world hop market.

The book is thoroughly researched, well documented, and highly accurate, so far as a nonexpert on hops can determine. Strausz's incidental information on agricultural activities in Yugoslavia is also discerning and accurate, and leads to the conclusion that he is a perceptive and informed observer. Though its immediate audience obviously is very limited, the book should be useful to a much wider readership for its penetrating insight into East European agriculture. It is to be hoped that similarly meritorious studies may soon be produced on the maize, wheat, oilseed, and livestock industries of the same countries. If the same degree of ability, scholarship, and information could be brought to bear on specific studies of these commodities, much light could be shed on the situation of Communist agriculture at the close of the 1960s.

EARL R. Leng University of Illinois

DREVNERUSSKAIA LITERATURA: KHRESTOMATIIA. Compiled by A. L. Zhovtis. Moscow: "Vysshaia shkola," 1966. 346 pp.

LITERATURNYE SVIAZI DREVNIKH SLAVIAN. Volume 23 of Trudy Otdela drevnerusskoi literatury. Leningrad: Akademiia nauk SSSR, Institut russkoi literatury (Pushkinskii dom), 1968. 343 pp.

A modern-language version of a medieval literary monument (or collection of monuments), even though extremely well done, is of limited usefulness. A professor of the native literature in France would never allow his students to study the Chanson de Roland only in the contemporary idiom, nor would an instructor in an English university limit himself to modern renderings of Chaucer. Therefore, it is difficult to understand what justification there could possibly be for Zhovtis's Drevnerusskaia literatura: Khrestomatiia, which is specifically intended for students in "gumanitarnie vuzy i fakul'tety" (fifteen thousand copies).

Curiously enough, this book is not the first of its kind. M. O. Skripil's Russkaia povest' XVII-ogo veka (1954) contained a separate section of modern Russian translations for the old texts given elsewhere in the book. Eremin's and Likhachev's Khudozhestvennaia proza kievskoi Rusi XI-XIII vv. (1957) also contained such translations. Finally, there was the earlier version of the book under review, Khrestomatiia po drevnei russkoi literature, edited by Zhovtis, Posse, et al. (AlmaAta, 1956).

The selections chosen for the present volume are disappointing. An unfortunate but familiar bias is betrayed in the omission of such works as the sermons of Kirill Turovsky and Metropolitan Ilarion, the Virgin's Descent into Hell, the Life of 